\title{
Developing self and peer assessment to improve student's appreciative critical ability in learning drama appreciation
}

\author{
Khafidatur Rohmah*; Endah Tri Priyatni; Heri Suwignyo \\ Universitas Negeri Malang \\ Jl. Semarang No. 5, Sumbersari, Lowokwaru, Kota Malang 65145, Jawa Timur \\ ${ }^{*}$ Corresponding Author. E-mail: khafidatur.rohmah.1702118@students.um.ac.id
}

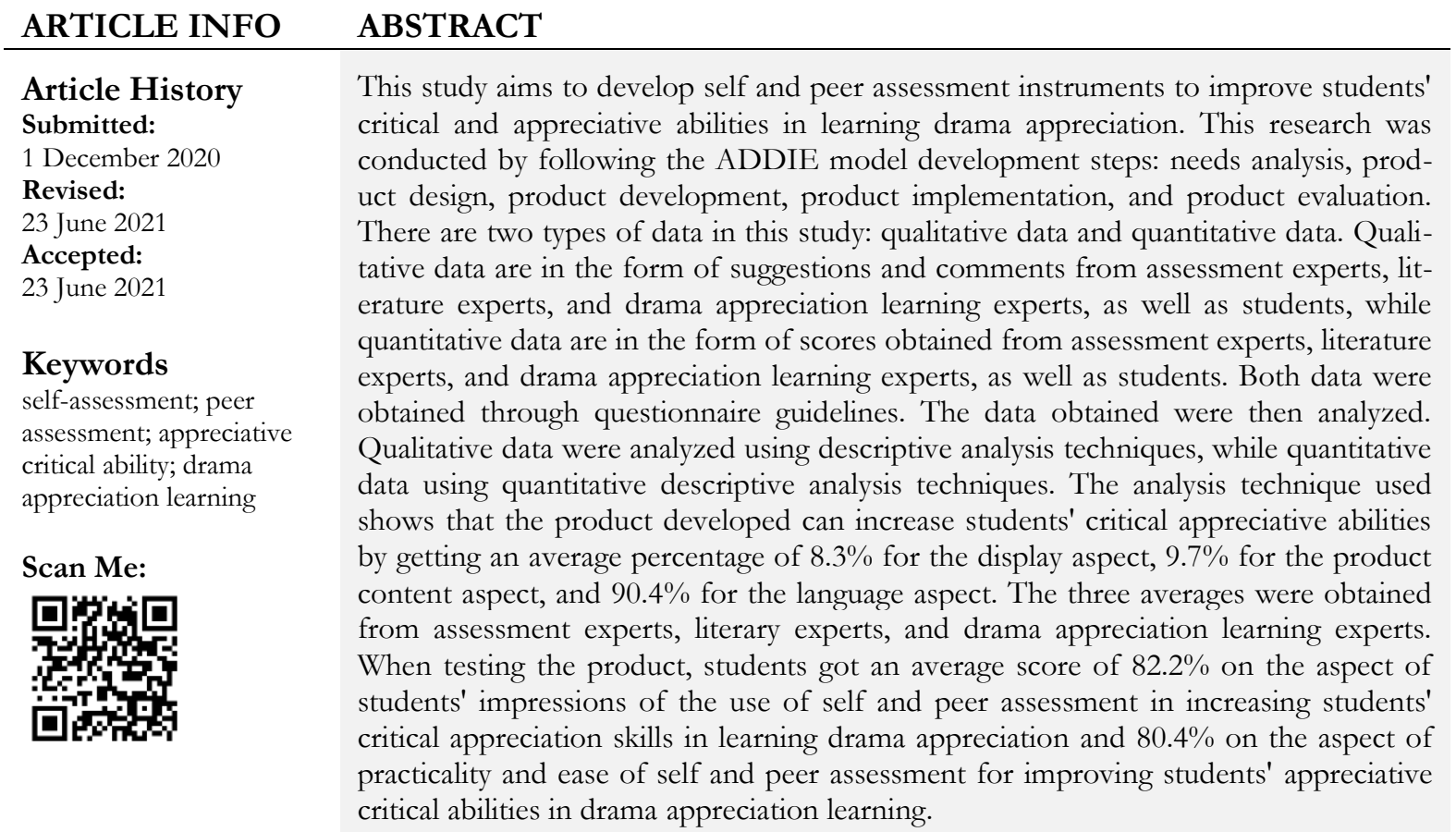

This is an open access article under the CC-BY-SA license.

How to cite:

Rohmah, K., Priyatni, E., \& Suwignyo, H. (2021). Developing self and peer assessment to improve student's appreciative critical ability in learning drama appreciation. Jurnal Penelitian dan Evaluasi Pendidikan, 25(1), 49-62. doi:https://doi.org/10.21831/pep.v25i1.36221

\section{INTRODUCTION}

Critical and appreciative abilities are several abilities that students must improve because with critical abilities, students can observe various problems that occur in daily life (Novtiar \& Aripin, 2017, p. 120). In addition, with critical abilities, students' academic abilities will be formed (Pamularsih, 2019). Students will obtain these abilities because the ability to think critically is self-regulation in deciding something that results in interpretation, analysis, evaluation, and inference, as well as exposure using evidence, concept, methodology, criteria, or contextual considerations on which to base the decisions (Facione, 2011). Another opinion says that critical skills include analyzing activities, submitting arguments, providing clarification, evidence, reasons, implications of opinion, and generalizing conclusions based on facts (Ariyatun \& Octavianelis, 2020, p. 35).

Appreciation is a characteristic of appreciation, which in the dictionary means appraisal or appreciation for something. The two abilities are related. Someone who will give an assessment must be based on appropriate and reasonable arguments. These arguments are obtained 
from critical abilities. In the world of literature, the appreciative ability is an activity in the form of recognizing literary works through feelings or inner sensitivity and understanding and acknowledging the values expressed by the author (Ismawati, 2017).

The level of appreciative critical ability of each individual is different. This can happen due to environmental and age factors. Likewise, junior high school students are likely to have different critical thinking abilities from high school students and students in college. Syahbana (2012, p. 45) says that junior high school students (aged 12-15 years) have not fully thought abstractly. However, they have started to be able to apply thinking patterns that can lead them to understand and solve problems, which is a form of the critical nature of junior high school children.

Seeing that critical and appreciative abilities benefit students, in learning activities, teachers should use models, strategies, learning instruments, or so on that can help students improve these two abilities. Juhji and Suardi (2018, p. 16) said that the task of teachers in the era of globalization must be able to develop students' critical thinking. In the dictionary, intelligence is an experience that one has is ready to be used when faced with new facts or conditions. That way, it is hoped that students can adjust to the globalization era.

There are several ways that teachers can improve these two abilities to students, one of which is by using self-assessment instruments and peer assessment in learning drama appreciation. Both assessment and learning are used to improve students' critical appreciation skills based on the characteristics of appreciative critical abilities. Yunita et al. (2018) said there are five keys related to critical thinking, namely practical, reflective, reasonable, trust and action, while according to Harsiati (2013, p. 128), in a nutshell, receptive appreciation activities are the ability to recognize, understand, analyze, compare, generalize, reflect, and assess the form and content of literary works.

In general, the assessment is carried out by the teacher, and without realizing it, the teacher hones his appreciative critical ability so that the increase in these two traits is dominant to the teacher, not to the student, even though students need these two abilities to support their learning even in everyday life. Therefore, self and peer assessment are used to increase students' appreciative critical abilities. Self and peer assessments are used to improve students' appreciative critical abilities in drama appreciation learning. Both assessments are carried out by students themselves in assessing the learning process, especially in assessing the achievement of drama appreciation learning indicators. Learning indicators in this study were developed based on basic competence 4.15 (interpreting traditional and modern dramas that are read and watched or heard). The indicators developed are learning objectives that will be achieved by students, which implicitly have appreciation activities. Table 1 describes learning indicators based on basic competencies 4.15.

Table 1. Explanation of Basic Competencies and Learning Indicators for Drama Main Materials to Improve Students' Appreciative Critical Thinking Skills

\begin{tabular}{|c|c|}
\hline Basic Competencies & Indicator \\
\hline \multirow[t]{3}{*}{ Interpreting the drama } & $\begin{array}{l}\text { Describe the relationship or suitability between the elements of } \\
\text { drama that is read and watched or heard. }\end{array}$ \\
\hline & Reflecting the contents of a drama story with real life. \\
\hline & Responding to the use of language as a medium of expression. \\
\hline
\end{tabular}

Drama learning is used to increase students' appreciative critical abilities because appreciation is individual. Students from one another are likely to have different appreciating points of view. They have the right to express arguments that they feel are correct. Ghufroni and Dewi (2019) said drama is a portrait of joy and sorrow, bittersweetness, and black and white of human life. Students are familiar with this and are part of the portrait of life; therefore, various types of drama literature were chosen to improve students' appreciative critical abilities. 
In this development research, there are a number of things that must be known first: self-assessment and its techniques and peer assessment and its techniques. These two things need to be known to make it easier to understand the concept of this development research.

First, self-assessment is a process assessment carried out by students to discover their specific weaknesses and abilities. According to Basuki and Hariyanto (2014, p. 70), self-assessment is a process that describes how students obtain information and reflect on their own learning. This self-assessment is also used to determine personal progress in knowledge, skills, learning processes, and attitudes. This assessment will guide students towards better awareness and understanding of themselves as learners. Self-assessment has several techniques that can be used to improve appreciative critical abilities, namely (1) self-reflection journals, (2) editor's checklists, and (3) learning journals. The following is an explanation of the three techniques.

The self-reflection journal is an assessment technique used by students to convey their learning experiences in achieving learning indicators. Moon (2013) said that a self-reflection journal leads to experiences. In this case, what is meant is an experience in the form of steps or strategies carried out and experiences of difficulties students face during learning in achieving indicators. There are two types of self-reflection journals developed in this study: self-reflection journals in the form of statements of steps students use in conveying their learning strategies in achieving indicators and self-reflection journals in the form of statements of difficulties experienced by students in achieving indicators.

The editor's checklist is an assessment technique used by students in classifying themselves into the categories of students who are successful or not successful in learning. This editor's checklist contains questions regarding the achievement of indicators with sentences that use the word 'I'. Knowing the classifications of students categorized as successful in doing the assignment provides constructive comments to students who have not been successful in doing the assignment. Wragg (2001) says that the main use of checklists is to stimulate active learning. In this technique, there are three adjectives that describe students' understanding: (1) clear which means I understand as a whole, (2) buggy (blur/foggy) which means that I understand most of the material, but some things are still unclear, and (3) muddy (dusty/dark) that means I do not understand at all.

Self-Reflection Journal (Step Statement)

Basic Competence: interpreting drama (traditional and modern) which is read and watched or heard. (filled in by the teacher)

Indicator: describes whether or not the theme is related to the setting in the drama. (filled in by the teacher)

Name:

Day and date:

The step I take in explaining whether or not a theme is related to the setting of a place is to first find out the drama theme and then identify the setting of the place and the nature of the place. The theme in the drama Sarjana Kambing is the aspirations of the village people (an explanation of how to determine the theme can be seen in the column marked with the lights below this column) and the setting is Irul's simple and clean house (terrace, dining room, living room, and kitchen), goat shed, vast rice fields, and solid Teguh' house.

Based on my steps, the theme elements with the place setting in the drama Sarjana Kambing have a relationship or correspondence, with the reason that all the places in the drama are settings that are rarely found in urban areas. Even if there is a setting in this place, it is not like the nature of the place in the village, such as the background of the rice fields which are very broad, the house is simple and clean, and again the goat cage in the city is rarely found, so the setting depicted in the drama is appropriate. with the theme of the ideals of the villagers.

Figure 1. Example of Self-assessment with Self-reflection Journal Techniques 
The learning journal is an assessment used at the end of the lesson to find out the learning process that has occured from the student's point of view. Yusuf (2017) argues that notes in learning journals can be in the form of personal observations, feelings, attitudes, perceptions, impressions, and opinions in response to readings, events, and experiences. Figure 1 shows an example of a self-assessment using a self-reflection journal technique (in the form of a step statement).

Second, peer assessment is a process assessment technique that can also improve students' appreciative critical abilities by involving fellow students to assess their respective work. Rochmiyati (2013) states that peer assessment as an alternative assessment gives students freedom in expressing opinions. This opinion is in the form of constructive comments as an improvement in the work of other students who have not reached the learning indicators. Peer assessment developed in this study is not in the form of numbers, but rather information that students can use to find out and improve their abilities in a certain subject matter. Liu and Carless (2006) say that in peer assessment, students can send more feedback and more quickly than teachers who provide comments. This is due to the teacher's limitations in providing sufficient feedback for the number of students so feedback from friends can be a central part of the learning process. Slamet (2020, p. 41) says that feedback is information communicated to students to modify thoughts or behavior to improve the quality of learning outcomes.

Peer assessment has several techniques that can be used to improve students' appreciative critical abilities: two stars and a wish and warm and cold feedback. Two stars and a wish is one of the process assessment techniques by students to assess their friends' work results by giving two stars for indicators that appear and one sign of hope for indicators that have not appeared. Wiliam (2011) states that two stars and a wish are a structured assessment technique for students to provide feedback on their friends' work results. In giving an assessment, students should not only give praise but also praise it accompanied by mentioning what form the praise is taking. This needs to be considered so each student can get constructive feedback.

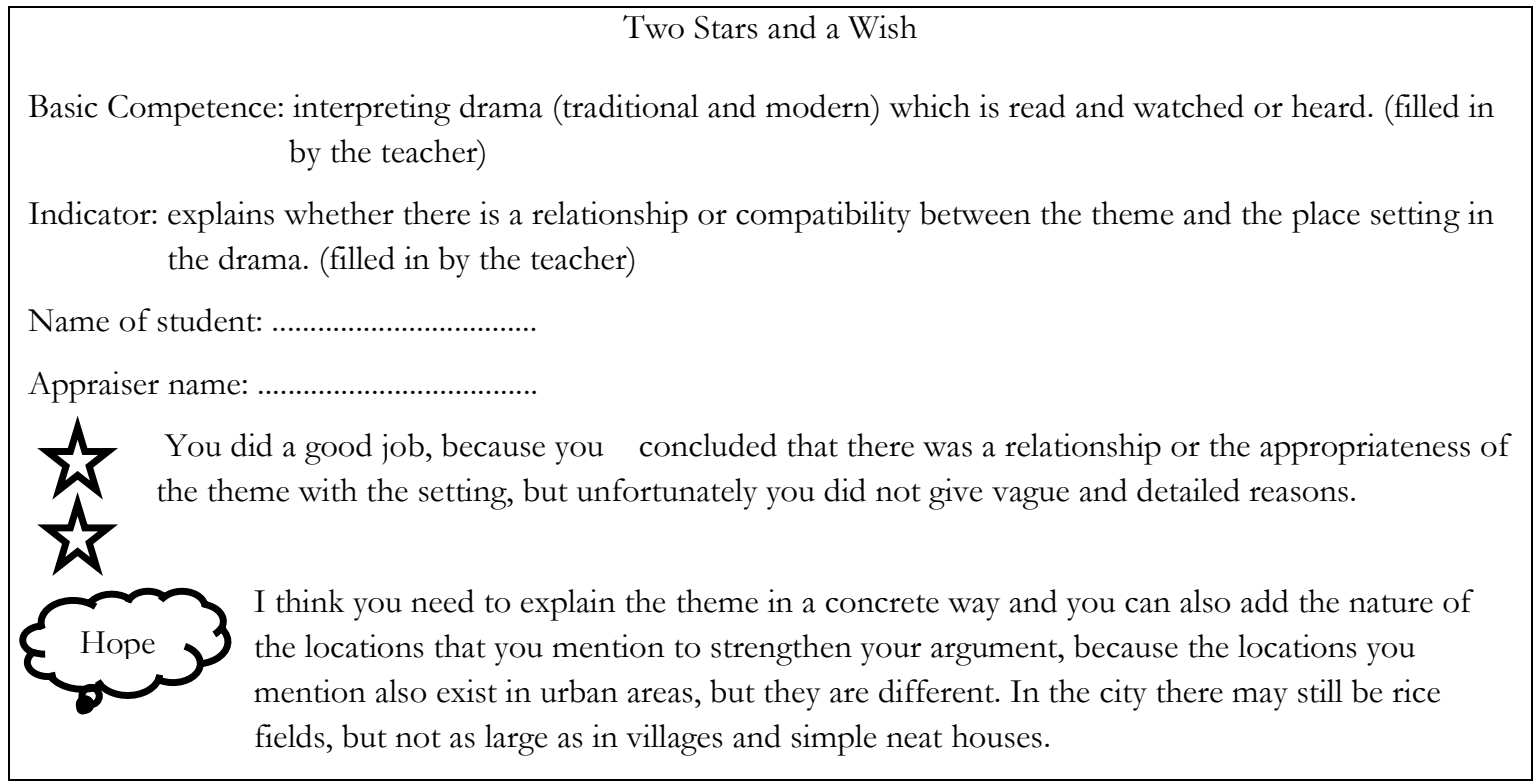

Figure 2. Example of Self-assessment Using the Two Stars and a Wish Technique

Warm and cold feedback is an assessment technique carried out by two students, and each student shares warm and cold feedback on the results of their work. Clark and Duggins (2016) says that warm feedback can include comments about assessments that meet learning objectives. In contrast, cold feedback can include comments on possible non-achievement of learning objectives, gaps, or problems. The way it works is that students in the clear category 
assess the results of their work in the dark/dark category for constructive comments. In this case, students can offer ideas or suggestions to strengthen the assessment they provide. Figure 2 shows an example of one of the peer assessments using the two stars and a wish technique.

In implementing self and peer assessment, the teacher must arrange learning steps to realize all the techniques used. The learning steps that can be used in implementing self and peer assessment in learning are as follows. First, the teacher must convey to students when using self and peer assessment in learning so students know the steps or activities carried out during the learning process according to the two assessments characteristics. Second, the teacher provides illustrations, techniques and examples of self and peer assessment in drama appreciation learning (supervised assignments). Third, teacher presents the drama script as an appreciation material. Four, students are given the task of reading a drama script with a time limit. Periodically, students are asked to record reading results (results of appreciation) and report them orally. Students who finish appreciating more quickly are asked to share their experiences or appreciation strategies in front of their peers so they can learn from them (self-reflection journal in the form of step statements). Five, students who still face difficulties in the process are asked to share their experiences and give feedback (self-reflection journal in the form of difficulty statements). Six, students commented on positive aspects of their friends' work in the form of suggestions or strategies for improving their friends (peer assessment). Seven, students provide constructive comments and feedback on aspects of their friends' work in accordance with the directions and rubrics given by the teacher (peer assessment). During the learning process, the teacher monitors and facilitates student activities.

\section{RESEARCH METHOD}

\section{Research Design}

The design of this study uses the ADDIE development model with five steps, namely analysis, design, development, implementation, and evaluation (Spector et al., 2014). The five steps can be seen in Figure 3.

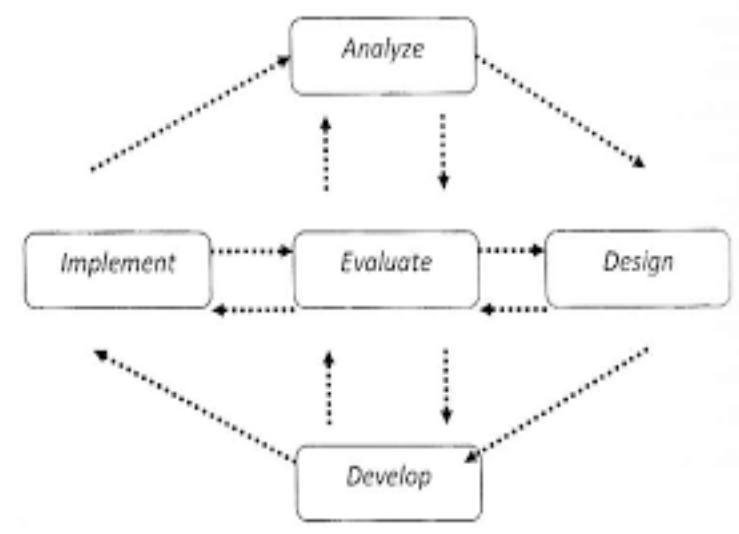

Figure 3. ADDIE Development Model

\section{Development Procedure}

At the analysis stage, preliminary research was carried out related to the dominant assessment conducted by the teacher. Besides, classroom observations were conducted to see whether assessment as learning is applied in learning, how it is applied, assessing various assessments used in schools through interview techniques.

The design stage was to design a product tailored to the product user (student), learning objectives, and the instrument's characteristics to be developed. What was done at this stage was making the steps for implementing assessment as learning in drama appreciation learning. 
At the development stage, there are four actions carried out. They are (1) preparation of test grids, (2) writing test items, (3) writing instructions and examples of test work, and (4) writing answer keys or scoring signs.

The implementation stage was to develop products in the form of self-assessment and peer-assessment instruments. The two instruments development is adjusted to the respective indicators in the basic competencies used. For self-assessment, there are three techniques developed: self-reflection journals, study journals, and editor's checklists. Two techniques have been developed for peer assessment: two stars and a wish and warm and cold feedback.

The evaluation stage was to assess the products developed based on the data obtained from questionnaires in the form of student and expert responses. This stage was used as an improvement so that the product that was developed is in accordance with the objectives.

The appearance aspect that needs to be improved is the cover image used and the book margins. The suggestions are obtained from learning experts. The content aspect that needs to be improved is the simplification of each step in compiling the instrument developed. These suggestions were from students, while the assessment experts suggested improving the content aspect by reviewing the steps developed so they can be used in other drama scripts.

\section{Data and Data Sources}

There are two data in this study: quantitative and qualitative data. Quantitative data in the form of scores from the expert team's validity before the product were implemented and obtained from the results of field trials (students) after using the product. Meanwhile, qualitative data were in the form of responses, suggestions, and criticism of the validity of the contents and constructs of the instruments developed from experts before implementation and from students after using the products developed. The sources of research data were categorized into two, namely experts (drama learning experts, assessment experts, and literature experts) and respondents (11 students from a madrasab tsanawiyah or junior high school).

\section{Research Instruments}

The instruments used in this development research were interview guidelines and a questionnaire. First, the interview guide was used during preliminary observations to interview practitioners (teachers). The interview guidelines were conducted openly, which only contained an outline of the interview topic. Second, the questionnaire guidelines were used to assess the results of products carried out by experts, practitioners, and respondents (students).

\section{Data Analysis Techniques}

Two data analysis techniques were used: qualitative descriptive and quantitative descriptive data analysis techniques. Qualitative descriptive analysis technique described data from the product trial results in the form of suggestions and comments from experts after validated and obtained from respondents (students) after using the products developed. These data were obtained from a questionnaire in the section giving criticism and suggestions for the product developed. Quantitative descriptive analysis technique was used to analyze quantitative data from the validation results of experts and field tests conducted by students after using the product.

Table 2. Table of Eligibility Criteria

\begin{tabular}{cccc}
\hline Scale & Achievement Level & Qualification & Follow-up \\
\hline 5 & $86-100$ & Very worthy & Implementation \\
4 & $71-85$ & Worthy & Implementation \\
3 & $56-70$ & Pretty decent & Implementation \\
2 & $41-55$ & Not feasible & Needs revision \\
1 & $\leq 40$ & Very unworthy & Needs revision \\
\hline
\end{tabular}


Both data were in the form of scores from filling out the questionnaire. Quantitative data analysis was conducted by collecting and analyzing numerical data from a questionnaire. The numerical data were then processed in percentage form using the percentage formula. After the percentage was known, it was described using the product eligibility criteria to interpret the feasibility of the resulting product by changing the five-scale achievement levels as presented in Table 2.

\section{FINDINGS AND DISCUSSION}

Based on the research objectives, namely developing assessment as learning products to improve students' appreciative critical abilities and testing the product's effectiveness, the results of the research are explained as follows.

\section{Product Specifications Developed}

The product specifications that were developed are adjusted to the conditions of the research subject. The specifications of the product developed are outlined in Table 3.

Table 3. Developed Product Specifications

\begin{tabular}{|c|c|}
\hline Part Name & Contents \\
\hline Part 1 Introduction & $\begin{array}{ll}\text { 1. } & \text { Purpose } \\
\text { 2. } & \text { Scope }\end{array}$ \\
\hline $\begin{array}{l}\text { Part II } \\
\text { Introduction }\end{array}$ & $\begin{array}{l}\text { 1. Definition of drama appreciation learning. } \\
\text { 2. Definition of assessment as learning. } \\
\text { 3. The use of assesment in learning drama appreciation. }\end{array}$ \\
\hline $\begin{array}{l}\text { Part III } \\
\text { Types of Assessment as Learning in Drama } \\
\text { Appreciation Learning }\end{array}$ & $\begin{array}{l}\text { 1. Self assessment } \\
\text { 1.1 Jurnal reflection } \\
1.2 \text { Editor's checklist } \\
1.3 \text { Study journal } \\
\text { 2. Peer assessment } \\
2.1 \text { Two stars and a wish } \\
2.2 \text { Warm and cold feedback }\end{array}$ \\
\hline $\begin{array}{l}\text { Part IV } \\
\text { Examples of Assessment as Learning in } \\
\text { Drama Appreciation Learning }\end{array}$ & $\begin{array}{l}\text { 1. Example of a self-reflection journal } \\
\text { 2. Sample checklist editor } \\
\text { 3. Journal of learning (learning journal) } \\
\text { 4. Two stars and a wish } \\
\text { 5. Example of warm and cold feedback }\end{array}$ \\
\hline $\begin{array}{l}\text { Part } \mathrm{V} \\
\text { Implementation of Assessment as Learning in } \\
\text { Drama Appreciation Learning }\end{array}$ & $\begin{array}{l}\text { Explanation of the implementation of assessment as learning } \\
\text { in drama appreciation learning, which contains assessment } \\
\text { and appreciation activities based on formulated learning } \\
\text { indicators }\end{array}$ \\
\hline Part VI Closing & $\begin{array}{l}\text { 1. Conclusion } \\
\text { 2. Suggestion }\end{array}$ \\
\hline
\end{tabular}

Table 3 in part $\mathrm{V}$ contains appreciation and critical thinking activities. The appreciation activities are described based on the basic competencies and the learning indicators which are defined in this study. In contrast, critical thinking activities are included in the assessment activities. Each appreciation and critical thinking activity is elaborated as follows.

\section{Appreciation Activities}

Appreciation activities are based on the basic competencies of learning on drama subject matter. Table 4 can be used as a consideration to find out the basic competencies and also the indicators of drama learning. The first indicator (4.15.1) is then translated into two points: (a) 
explaining whether there is a relationship or suitability of the theme with the setting in the drama, and (b) explaining whether there is a relationship or suitability of language (dialogue) with characterizations in drama.

Table 4. Explanation of Basic Competencies and Learning Indicators

\begin{tabular}{ccl}
\hline \multicolumn{1}{c}{ Basic Competencies } & & \multicolumn{1}{c}{ Indicator } \\
\hline $\begin{array}{ccl}\text { 4.15 Interpreting the drama (tradi- } \\
\text { tional and modern) that is read }\end{array}$ & 4.15 .1 & $\begin{array}{l}\text { Describe the relationship or suitability between the elements } \\
\text { of the drama that is read and watched or heard. }\end{array}$ \\
and watched or heard. & 4.15 .2 & $\begin{array}{l}\text { Reflecting the contents of a drama story with real life. } \\
\end{array}$ \\
& 4.15 .3 & Responding to the use of language as a medium of expression. \\
\hline
\end{tabular}

The three indicators are translated into several appreciation activities. For the first indicator, point one is translated into four appreciative activities: (1) reading a drama script, (2) identifying the elements of drama, (3) noting the intrinsic elements, and (4) explaining the existence of a relationship or theme to the setting. For the first indicator, the second point is translated into four appreciative activities: (1) reading the drama script, (2) identifying each character and characterization as well as the language (dialogue) in the drama, (3) recording the results of character identification and characterization and the language used, and (4) explaining the relationship or suitability of language (dialogue) with characterizations. The second indicator is translated into four appreciative activities: (1) reading the drama script, (2) identifying each character and characterization and dialogue (language) in the drama, (3) recording the results of character identification and characterization along with the language used in drama, and (4) explaining the relationship or suitability of language (dialogue) with characterizations. The third indicator is translated into four appreciative activities: (1) reading the drama scripts, (2) identifying the language in drama, (3) recording the results of language identification in drama, and (4) responding to the use of language as a medium of expression.

The aforementioned appreciating activities are at the level of being fond of and reacting. Waluyo (2002) says there are four levels of appreciation, namely (1) the level of liking, (2) the level of enjoyment, (3) the level of reaction, and (4) the level of production. The activities of reading drama scripts, identifying the intrinsic elements of drama, and discussing the content or intrinsic elements of drama, then the activities of appreciating those described are categorized at the level of liking and reacting. It is in accordance with Amri and Damaianti (2017, p. 190) that appreciating activities are categorized at the level of liking if students read drama script independently or in groups with teacher directions, while categorized at the level of reaction if students can discuss well and issue an opinion about the content of the drama script.

\section{Critical Thinking Activities}

Critical thinking activities are contained in assessment activities described based on the basic competencies of learning on the subject matter of drama as in Table 4 . The three indicators listed in Table 4 are translated into four assessment activities for each indicator. The assessment activities are in the form of (1) conducting an assessment using the self-reflection journal technique, (2) conducting an assessment using the checklist editor technique, (3) conducting an assessment using the two stars and a wish technique, and (4) conducting an assessment using the technique of warm and cold feedback.

Based on the characteristics of the four techniques, students are required to think critically when assessing the results of their work or their friends' work because they must provide accurate and easy-to-understand explanations for their assessment results so their friends can accept the explanation. Nuryanti et al. (2018, p. 155) state that critical thinking skills include basic clarification skills, basic decision making, concluding, providing a further explanation, estimation, and integration, as well as additional abilities. Based on this explanation, the assess- 
ment activities in this research product include the ability to make decisions, conclusions, provide further explanations, and additional capabilities in the form of giving practical advice. These abilities are realized based on the characteristics of the four assessments used in this study. These abilities will appear in each indicator; if there are five indicators (including the elaboration of the first point indicator), then students will do critical thinking activities five times. By doing the assessment activity five times, it is expected that the students' thinking ability will increase. This is in accordance with the explanation of Suratno and Kurniati (2017, p. 2) that critical thinking skills can be sharpened by accustoming students to be actively involved in solving problems that require critical thinking skills.

\section{Developed Product Effectiveness}

The product's effectiveness is obtained from the validation process of the drama appreciation learning experts and the respondents (students) after the product trial. The data from the product trial results are in the form of numerical and verbal data. Numerical data is calculated from the score obtained through a questionnaire, while the verbal data is in the form of criticism and suggestions obtained from experts on the product feasibility test results. Figure 4 presents the instrument used to determine the effectiveness of the product developed.

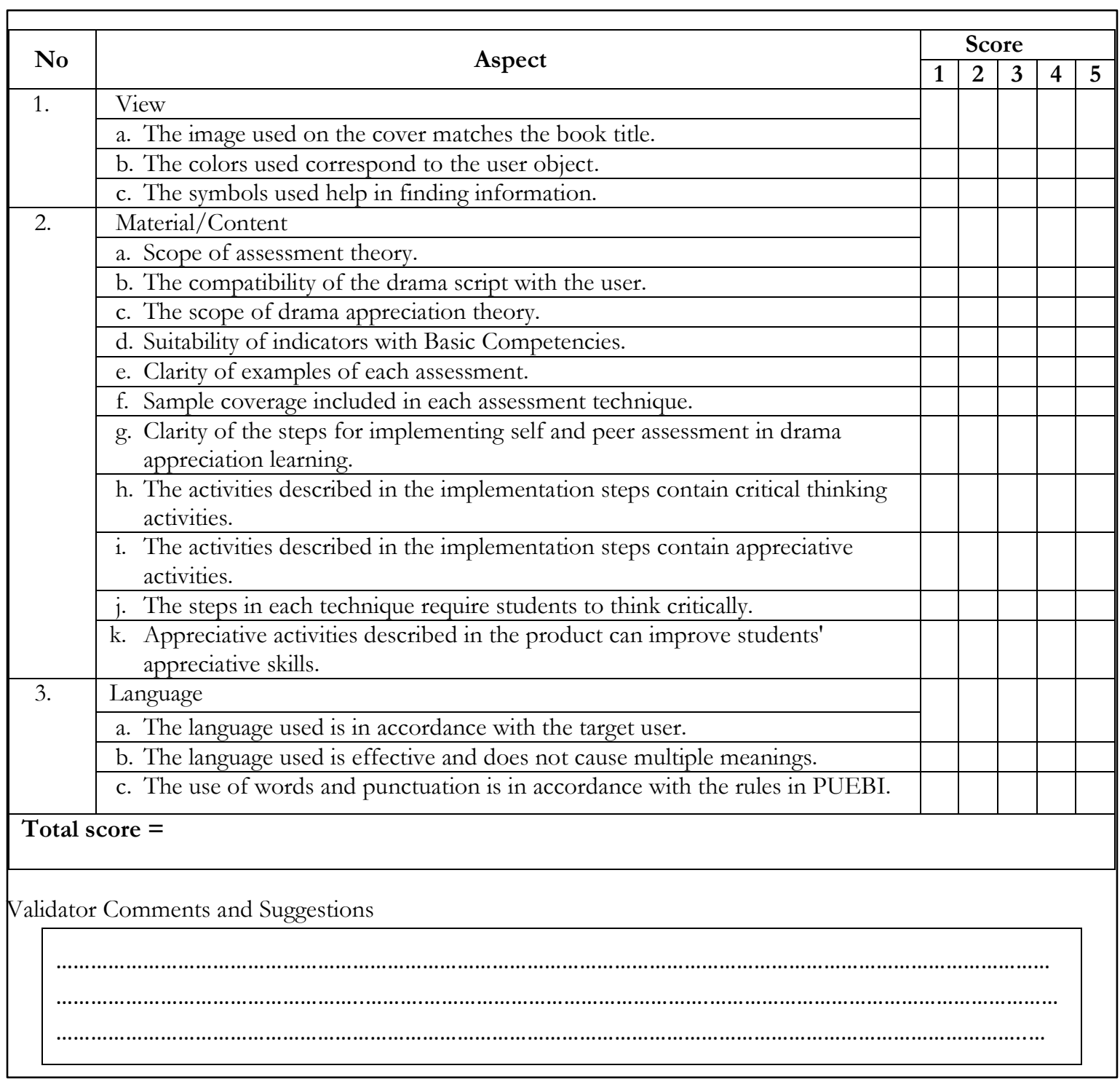

Figure 4. Data Collection Instruments by Experts 


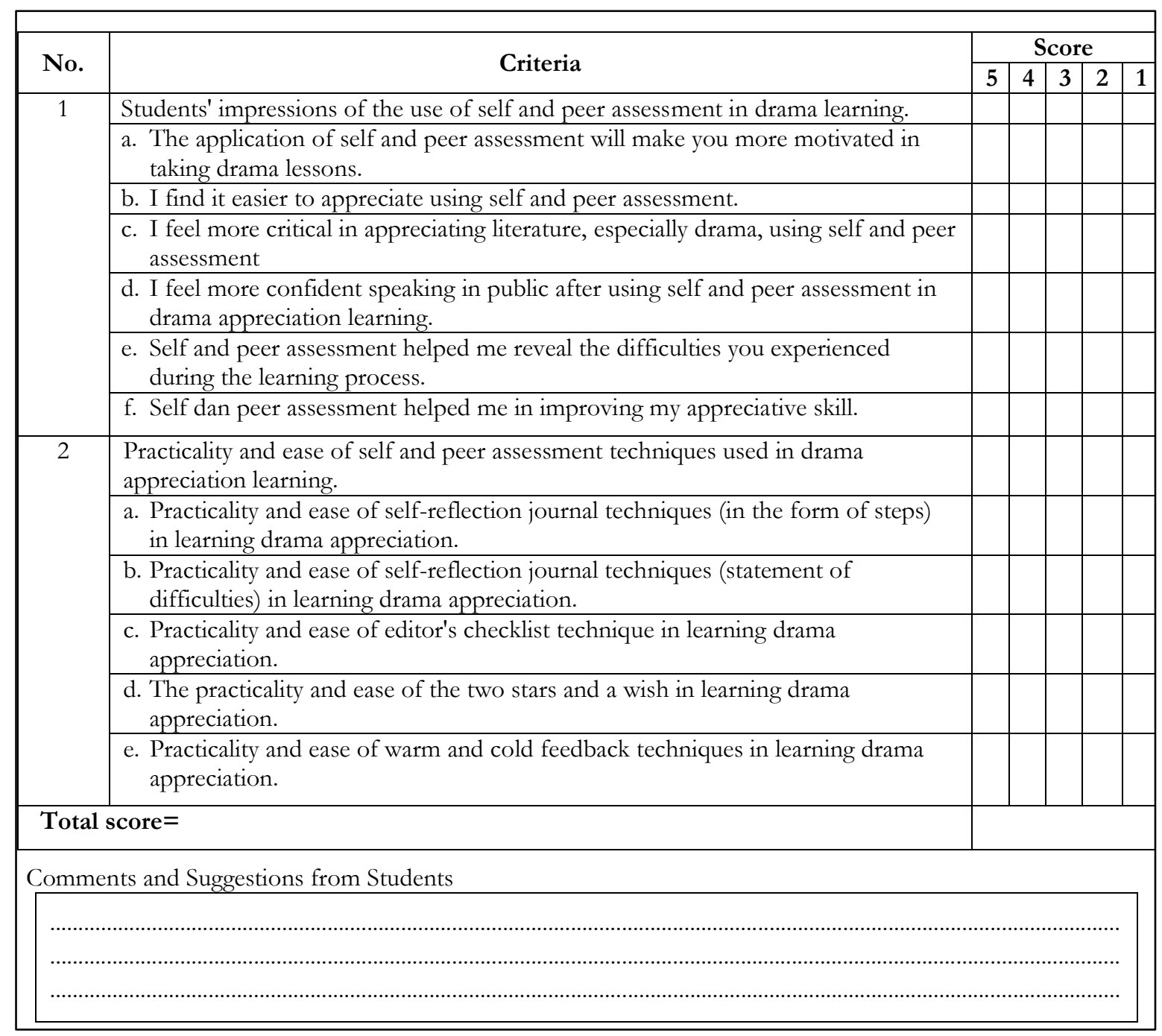

Figure 5. Data Collection Instruments by Students

Based on the instrument to determine the effectiveness of the developed product from Figure 4 and Figure 5, the score obtained can be found. Each of it is elaborated as follows.

\section{Acquiring Data from Assessment Experts and Drama Learning Experts}

There are three aspects assessed at the validation stage of the assessment expert and drama learning expert: (1) the aspect of book appearance, (2) the material/book content aspect, and (3) the language aspect. The following is an explanation of each of these aspects.

Aspects of Book Display

Three eligibility criteria are assessed in this aspect: (1) the suitability of the image on the cover with the book title, (2) the suitability of the color with the user object, and (3) the suitability of the symbols used in the book. The results of the due diligence are shown in Table 5 .

Table 5. Feasibility Test Results from Display Aspects (Numerical Data)

\begin{tabular}{cccc}
\hline Test Subject & Percentage & Qualification & Follow-up \\
\hline Assessment expert & 60 & Pretty decent & Implementation \\
Drama learning expert & 80 & Worthy & Implementation \\
Literary expert & 73 & Worthy & Implementation \\
Mean & 83 & Worthy & Implementation \\
\hline
\end{tabular}


Aspects of Book Content

Nine eligibility criteria are assessed in this aspect: (1) the scope of the assessment theory, (2) the suitability of the drama script with the user, (3) the coverage of drama appreciation theory, (4) the suitability of indicators with basic competencies, (5) the clarity of examples - each assessment, (6) the scope of examples included in each assessment technique, (7) clarity of the steps for implementing self and peer assessment in drama appreciation learning, (8) the activities described in the implementation steps containing critical thinking activities, and (9) the activities described in the implementation steps containing appreciative activities. The results of the due diligence are presented in Table 6.

Table 6. The Results of the Feasibility Test for the Aspect of Book Contents (Numerical Data)

\begin{tabular}{cccc}
\hline Test Subject & Percentage & Qualification & Follow-up \\
\hline Assessment expert & 62.23 & Pretty decent & Implementation \\
Drama learning expert & 84.4 & Worthy & Implementation \\
Literary expert & 100 & Very worthy & Implementation \\
Mean & 92.7 & Very worthy & Implementation \\
\hline
\end{tabular}

Language Aspects

Three eligibility criteria are assessed in this aspect: (1) the suitability of the language with target user, (2) the language used is effective and does not cause double meanings, and (3) the suitability of the use of words and punctuation in PUEBI. The results of the due diligence are explained in Table 7.

Table 7. Test Results of the Language Aspect (Numerical Data)

\begin{tabular}{cccc}
\hline Test Subject & Percentage & Qualification & Follow-up \\
\hline Assessment expert & 60 & Pretty decent & Implementation \\
Drama learning expert & 80 & Worthy & Implementation \\
Literary expert & 93.3 & Very worthy & \\
Mean & 90 & Very worthy & Implementation \\
\hline
\end{tabular}

\section{Field Trial Results (Students)}

Two aspects were assessed in the field test: (1) students' impressions regarding the use of assessment as learning to improve their appreciative critical abilities in learning drama appreciation and practicality, (2) the ease of self- and peer-assessment techniques used to improve students' appreciative critical abilities in drama appreciation learning. In the field product trial stage, students also provide suggestions for product improvements developed based on their experiences (Table 8). The explanation on each of these aspects is as follows.

Table 8. Product Improvement Suggestions (Verbal Data)

\begin{tabular}{ll}
\hline \multicolumn{1}{c}{ Test Subject } & Product Improvement Suggestions \\
\hline Assessment expert & - The AaL construct needs to be reviewed, so it includes both the process and \\
& results. \\
& $\begin{array}{l}\text { The giving of examples is too specific, so it cannot be used for assessment of } \\
\text { other texts with the same style. }\end{array}$ \\
Drama learning expert & Improve product quality in terms of appearance (images and margins). \\
\hline
\end{tabular}

Aspects of Student Impression of Self- and Peer-Assessment in Increasing Students' Critical Appreciative Ability

Five eligibility criteria are assessed at this stage, namely (1) self- and peer-assessment motivate students to take part in drama appreciation learning, (2) self- and peer-assessment 
eases students appreciate drama by using self and peer assessment, (3) self- and peer-assessment increases critical abilities students appreciate drama, (4) self- and peer-assessment increases students' sense of confidence when speaking in public, and (5) self- and peer-assessment helps students express difficulties experienced during learning. The test results are described in Table 9.

Table 9. Feasibility Test Results in the Form of Students' Impressions of Self- and PeerAssessment in Improving Students' Appreciative Critical Ability

\begin{tabular}{cccc}
\hline Test Subject & Percentage & Qualification & Follow-up \\
\hline Students & 82 & Worthy & Implementation \\
Mean & 82 & Worthy & Implementation \\
\hline
\end{tabular}

Practical Aspects and Ease of Self- and Peer-Assessment in Increasing Students' Critical Appreciative Ability

Five eligibility criteria were assessed at this stage, namely (1) the practicality and ease of the self-reflection journal technique (in the form of steps) in learning drama appreciation, (2) the practicality and convenience of the self-reflection journal technique (statement of difficulty) in learning drama appreciation, (3) the practicality and convenience of the editor's checklist technique in learning drama appreciation, (4) the practicality and convenience of the two stars and a wish technique in learning drama appreciation, and (5) the practicality and convenience of the warm and cold feedback technique in learning drama appreciation. The results of the feasibility test are explained in Table 10, and the explanation on the product improvement suggestions is shown in Table 11.

Table 10. Results of Practicality and Ease of Self-Assessment and Peer-Assessment in Improving Students' Appreciative Critical Ability

\begin{tabular}{cccc}
\hline Test Subject & Percentage & Qualification & Follow-up \\
\hline Students & $80.4 \%$ & Worthy & Implementation \\
\hline Mean & $80.4 \%$ & Worthy & Implementation \\
\hline
\end{tabular}

Table 11. Explanation of Product Improvement Suggestions (Verbal Data)

\begin{tabular}{|cl|}
\hline Test Subject & \multicolumn{1}{c|}{ Product Improvement Suggestions } \\
\hline Students & 1. Change the language according to the students. \\
& 2. The preparation of self-assessment techniques needs to be simplified for beginners. \\
3. Provide a self-assessment step related to identifying the intrinsic element in the drama. \\
4. The technique of self-reflection journals needs to be simplified. \\
5. Simplify the steps for implementing self and peer assessment in drama appreciation \\
lessons.
\end{tabular}

Based on the explanation in the introduction and the results of the data obtained, selfand peer-assessment can be categorized as a student-centered learning process. This is because students are active during learning. It is said to be active because students themselves assess the results of their work, and students provide constructive feedback using the developed assessment techniques. In addition, students can also try and find solutions to the problems they face in achieving learning indicators. Cahyadi et al. (2019, p. 207), in their research, said that the method used in learning which can make students active in learning both in attitude, knowledge, and skills, is student-centered learning. Learning that keeps students active is one of the characteristics of innovative learning strategies. Supriyadi (2017, p. 209) states that with innovative learning, students can learn actively, creatively, and innovatively. The discussion also explained that the emergence of active attitudes and creative and innovative abilities is an effort to create student-centered learning so that students have competence. 


\section{CONCLUSION}

Self- and peer-assessment is one type of assessment carried out by students during learning to identify students' strengths and weaknesses in achieving learning goals. These assessments have their own techniques that can improve students' critical and appreciative abilities through learning drama. For self-assessment, there are three techniques used, namely (1) self-reflection journal technique, (2) checklist editor technique, and (3) learning journal technique. For peer assessment, two techniques are used, namely two stars and a wish and warm and cold feedback. Based on the data obtained, self- and peer-assessment are feasible to increase students' critical-appreciative abilities in learning drama appreciation.

\section{ACKNOWLEDGMENT}

The authors thank the Directorate of Research and Community Service, the DirectorGeneral of Research and Development Strengthening, and the Ministry of Education and Culture for awarding a research grant in 2020. We hope that the research can contribute to the world of education in Indonesia.

\section{REFERENCES}

Amri, U., \& Damaianti, V. S. (2017). Pengaruh penggunaan teknik bermain drama melalui teater tradisional Randai berbasis kepercayaan diri terhadap kemampuan apresiasi drama. EduHumaniora: Jurnal Pendidikan Dasar Kampus Cibiru, 8(2), 186-197. https://doi.org/10.17509/eh.v8i2.5141

Ariyatun, A., \& Octavianelis, D. F. (2020). Pengaruh model problem based learning terintegrasi stem terhadap kemampuan berpikir kritis siswa. JEC: Journal of Educational Chemistry, 2(1), 33-39. https://doi.org/10.21580/jec.2020.2.1.5434

Basuki, I., \& Hariyanto, H. (2014). Asesmen pembelajaran. Rosdakarya.

Cahyadi, E., Dwikurnaningsih, Y., \& Hidayati, N. (2019). Peningkatan hasil belajar tematik terpadu melalui model project based learning pada siswa sekolah dasar. Jartika: Jurnal Riset Teknologi Dan Inovasi Pendidikan, 2(1), 205-218.

Clark, S., \& Duggins, A. S. (2016). Using quality feedback to guide professional learning: A framework for instructional leaders. Corwin Press.

Facione, P. A. (2011). Critical thinking: What it is and why it counts. Measured Reasons and the California Academic Press.

Ghufroni, G., \& Dewi, M. R. (2019). Pengembangan bahan ajar bermain drama dengan model pembelajaran SAVI pada siswa SMA. Jurnal Ilmiah SEMANTIKA, 1(1), 31-46. http://jurnal.umus.ac.id/index.php/semantika/article/view/80

Harsiati, T. (2013). Asesmen pembelajaran Bahasa Indonesia. UM Press.

Ismawati, E. (2017). Mantra Bumi karya Aprinus Salam sebagai bahan ajar apresiasi sastra. PIBSI XXXIX, 671-681. http://eprints.undip.ac.id/58822/

Juhji, J., \& Suardi, A. (2018). Profesi guru dalam mengembangkan kemampuan berpikir kritis peserta didik di era globalisasi. Geneologi PAI: Jurnal Pendidikan Agama Islam, 5(1), 16-24. http://jurnal.uinbanten.ac.id/index.php/geneologi/article/view/1043

Liu, N.-F., \& Carless, D. (2006). Peer feedback: The learning element of peer assessment. Teaching Higher Education, 11(3), 279-290. https://doi.org/10.1080/13562510600680582 
Moon, J. A. (2013). Reflection in learning and professional development: Theory and practice. Routledge. https://doi.org/10.4324/9780203822296

Novtiar, C., \& Aripin, U. (2017). Meningkatkan kemampuan berpikir kritis matematis dan kepercayaan diri siswa SMP melalui pendekatan Open Ended. PRISMA, 6(2), 119-131. https://doi.org/10.35194/jp.v6i2.122

Nuryanti, L., Zubaidah, S., \& Diantoro, M. (2018). Analisis kemampuan berpikir kritis siswa SMP. Jurnal Pendidikan: Teori, Penelitian, Dan Pengembangan, 3(2), 155-158. http://journal.um.ac.id/index.php/jptpp/article/view/10490

Pamularsih, P. (2019). Pengaruh penggunaan model pembelajaran Cooperative Reading and Composition (CIRC) dan kemampuan berpikir kritis terhadap kemampuan apresiasi cerpen siswa SDN Mrayan Kabupaten Ponorogo. Linguista: Jurnal Ilmiah Bahasa, Sastra, Dan Pembelajarannya, 2(2), 106-112. https://doi.org/10.25273/linguista.v2i2.3699

Rochmiyati, R. (2013). Model peer assessment pada pembelajaran kolaboratif elaborasi IPS terpadu di sekolah menengah pertama. Jurnal Penelitian Dan Evaluasi Pendidikan, 17(2), 333-346. https://doi.org/10.21831/pep.v17i2.1704

Slamet, S. S. (2020). Hubungan strategi umpan balik (feedback), motivasi berprestasi dan hasil belajar dalam pembelajaran PPKn di SMK. PINUS: Jurnal Penelitian Inovasi Pembelajaran, 5(2), 39-56. https://doi.org/10.29407/pn.v5i2.14539

Spector, J. M., Merrill, M. D., Elen, J., \& Bishop, M. J. (Eds.). (2014). Handbook of research on educational communications and technology. Springer New York. https://doi.org/10.1007/978-1-4614-3185-5

Supriyadi, S. (2017). Pembelajaran bahasa dan sastra Indonesia yang inovatif. Prosiding Seminar Nasional \#3: Bahasa Dan Sastra Indonesia Dalam Konteks Global, 209-218. http://jurnal.unej.ac.id/index.php/fkip-epro/article/view/4871

Suratno, S., \& Kurniati, D. (2017). Implementasi model pembelajaran math-science berbasis performance assessment untuk meningkatkan kemampuan berpikir kritis siswa di daerah perkebunan kopi Jember. Jurnal Penelitian Dan Evaluasi Pendidikan, 21(1), 1-10. https://doi.org/10.21831/pep.v21i1.11799

Syahbana, A. (2012). Peningkatan kemampuan berpikir kritis matematis siswa SMP melalui pendekatan contextual teaching and learning. Edumatica: Jurnal Pendidikan Matematika, 2(1), 45-57. https://online-journal.unja.ac.id/index.php/edumatica/article/view/604

Waluyo, H. J. (2002). Drama: Teori dan pengajarannya (A. Wulandari (Ed.)). Hanindita Graha Widia.

Wiliam, D. (2011). Embedded formative assessment - Practical strategies and tools for K-12 teachers. Solution Tree Press.

Wragg, E. C. (2001). Assessment and learning in the secondary school. Routledge.

Yunita, N., Rosyana, T., \& Hendriana, H. (2018). Analisis kemampuan berpikir kritis matematis berdasarkan motivasi belajar matematis siswa SMP. JPMI (Jurnal Pembelajaran Matematika Inovatif), 1(3), 325-332. https://doi.org/10.22460/jpmi.v1i3.p325-332

Yusuf, A. M. (2017). Asesmen dan evaluasi pendidikan. Kencana. 